\title{
ПІДГОТОВКА ФАХІВЦІВ У СИСТЕМІ ХОСПІСНОЇ ТА ПАЛІАТИВНОЇ ДОПОМОГИ НА ПРИКЛАДІ КОМУНАЛЬНОГО ЗАКЛАДУ «БЕРИСЛАВСЬКИЙ МЕДИЧНИЙ КОЛЕДЖ» ХЕРСОНСЬКОЇ ОБЛАСНОЇ РАДИ
}

\author{
А. О. Шевченко
}

\author{
ДВНЗ «Тернопільський державний медччний університет \\ імені І. Я. Горбачевського МОЗ Украӥни"
}

\begin{abstract}
У статті висвітлено проблему підготовки фахівців у системі хоспісної та паліативної допомоги, проаналізовано готовність студентів до надання такої допомоги на прикладі Комунального закладу «Бериславський медичний коледж» Херсонської обласної ради. Викладач повинен донести до студентів усвідомлення мети паліативної допомоги, яка полягає в підтримці якості життя у його фінальній стадії, максимальному полегшенні фізичних та моральних страждань пацієнта та його близьких, а також збереження людської гідності пацієнта наприкінці життя.
\end{abstract}

\section{PREPARATION OF PROFESSIONALS IN THE SYSTEM OF HOSPICE AND PALLIATIVE CARE IN THE EXAMPLE OF BERYSLAV MEDICAL COLLEGE}

\section{A. O. Shevchenko}

\section{HorbachevskyTernopil State Medical University}

\begin{abstract}
The article is devoted to the problem of training specialists in the system of hospice and palliative care, analyzed the readiness of students to provide such assistance on the example of Beryslav Medical College. The teacher must inform students on the purpose of palliative care, which is to maintain the quality of life at its final stage, maximizing the physical and moral suffering of the patient and his relatives, and preserving the human dignity of the patient at the end of his life.
\end{abstract}

Вступ. Паліативна допомога $\epsilon$ важливою складовою системи охорони здоров'я та соціального захисту громадян України і забезпечує реалізацію прав людини на гідне завершення життя та максимальне зменшення болю і страждань. Відповідно до рекомендацій ВОО3 та Комітету Міністрів ради Європи, паліативна допомога має стати одним із пріоритетних напрямків політики охорони здоров'я в європейському регіоні.

Збільшення в Україні кількості хворих із невиліковними захворюваннями та обмеженим прогнозом тривалості життя зумовило гостру необхідність організації та удосконалення підготовки фахівців із паліативної допомоги населенню [6].

Вже багато років поспіль питаннями підготовки медичних сестер із паліативної та хоспісної допомоги в Україні займаються такі фахівці, як Т. І. Чернишенко (директор Державної установи «Центральний методичний кабінет підготовки молодших спеціалістів» МОЗ України), С. О. Ястремська (директор ННІ

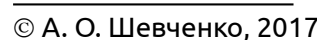

медсестринства ДВНЗ «Тернопільський державний медичний університет імені І. Я. Горбачевського МОЗ України»), В. Й. Шатило (ректор), П. В. Яворський (Житомирський інститут медсестринства), М. Б. Шегедин (директор Львівського державного медичного коледжу ім. Андрея Крупинського), І. Я. Губенко (директор), І. В. Радзієвська, Л. П. Бразалій (Черкаський медичний коледж).

Завдання:

- обґрунтувати роль медичної сестри в системі хоспісної та паліативної допомоги;

- визначити професійну та психологічну готовність студентів коледжу для надання паліативної допомоги.

Основна частина. На даний час медична сестра уособлює наймасовішу медичну професію в Україні. Найважливішими завданнями професійної діяльності сучасної медичної сестри є: комплексний всебічний догляд за пацієнтами і полегшення їх страждань, відновлення здоров'я та реабілітація, сприяння зміцненню здоров'я та попередження захворювань. 
Істотне місце відводять ролі медсестри саме в паліативній медицині. У паліативній медицині багато уваги приділяють питанням медсестринської діагностики: медсестринському діагнозу або проблемам пацієнта [3, 7].

Освіта медичних сестер є одним із пріоритетних напрямків стратегії успішного розвитку паліативної допомоги як галузі охорони здоров'я. Адже за належного навчання медичні сестри зможуть відігравати ключову роль у наданні паліативного догляду пацієнтам та їхнім родинам у хоспісах чи відділеннях паліативного догляду, де паліативний догляд перетворюється на базовий, невід'ємний компонент комплексного догляду за пацієнтами, які його потребують. Так, ще у 1989 р. експерти ВООЗ рекомендували включити основні положення паліативної медицини та основні принципи лікування хронічного больового синдрому в загальні програми навчання всіх спеціалістів охорони здоров'я; проводити післядипломне навчання медичних працівників із питань паліативної допомоги [5].

У 2011 р. Міністерством охорони здоров'я України затверджені навчальні програми з дисциплін:

- «Медсестринство в геронтології, геріатрії та паліативній медицині» для підготовки медичних сестер;

- «Геронтологія, геріатрія та паліативна медицина» для підготовки фельдшерів;

- «Медсестринство в паліативній і хоспісній медицині» для підготовки медичних сестер [6].

I тому стає зрозумілим, що питання хоспісної та паліативної допомоги потребує комплексного вирішення. Медичні сестри насамперед та інші медичні фахівці повинні бути професійно і психологічно підготовленими до надання паліативної допомоги ще на етапі додипломної освіти у вищих медичних навчальних закладах [6].

у Бериславському медичному коледжі на додипломному рівні це питання охоплює певний перелік дисциплін із відповідною тематикою, заходи, присвячені цій проблемі, науково-дослідницькі роботи студентів, гуртки.

Викладання питань паліативної та хоспісної допомоги потребує попереднього вивчення ряду клінічних та допоміжних дисциплін, що дозволить розуміти та засвоювати питання, пов' язані з проблемами та потребами пацієнтів, які вмирають. Без знань основ медсестринства, догляду за хворими, маніпуляційної техніки, етики та деонтології, медичної психології та основ міжособистісного спілкування, медсестринства в онкології та ряду інших дисциплін важко було б уявити засвоєння майбутніми медсестрами паліативної та хоспісної допомоги [6].
Післядипломна підготовка медичних сестер за цим напрямком ведеться в Бериславському медичному коледжі на курсах підвищення кваліфікації «Домашня опіка з догляду за тяжкохворими».

Медичні сестри повинні володіти педагогічними вміннями та навичками, щоб навчити пацієнта і його родичів елементам догляду, гігієни та контролю симптомів. У медичному коледжі на практичних заняттях з основ медсестринства приділяють велику увагу питанням навчання родичів пацієнтів, медсестринській педагогіці. Студенти мають змогу засвоїти та відтворити плани навчання: навчання родичів пацієнтів із порушенням функції кишок, підшкірного введення інсуліну, навчання родичів пацієнта профілактиці пролежнів тощо. Поглиблюють свої знання в цьому напрямку студенти і в гуртку «Медсестринство». Вони під керівництвом викладача для тяжкохворих виготовляють протипролежневі ватно-марлеві підкладні кола, подушки, навчають родичів тяжкохворих виготовляти такі засоби в домашніх умовах, проводити профілактику пролежнів, роздруковують інструкції щодо використання різноманітних протипролежневих засобів.

На виконання завдань Стратегії розвитку паліативної допомоги в Україні на 2015-2025 рр. у коледжі постійно проводять комплекс заходів.

3 метою підвищення інформованості студентів коледжу та населення Бериславського району про проблеми паліативної допомоги та хоспісів, сприяння у створенні умов для того, щоб люди могли висловити власні думки про проблему, підвищення розуміння медичних, соціальних, практичних і духовних потреб людей, які мають невиліковні захворювання та членів їх сімей, щорічно у другу суботу жовтня викладачами сестринської справи та догляду за хворими разом зі студентами проводять Всесвітній день хоспісної та паліативної допомоги [7].

Протягом 2015-2017 рр. студенти II курсу проводили науково-дослідницьку роботу з дисципліни «Основи медсестринства» на тему: «Проблеми та недоліки хоспісної та паліативної медицини в Херсонській області. Шляхи вирішення». Студенти під керівництвом викладача серед населення проводили опитування за такими питаннями:

- Чи знаєте Ви, що таке паліативна допомога?

- Чи стикалися Ви або Ваші рідні з проблемою догляду за безнадійно хворими або літніми людьми?

- Як Ви вважаєте, чи достатньо проінформоване населення про існуючі проблеми паліативної допомоги?

- 3 якими основними проблемами стикаються люди при наданні паліативної допомоги? 
- Як Ви вважаєте, чи необхідно проводити соціальні акції та інформаційні кампанії для висвітлення даної тематики?

Результатом роботи стали обрахунки результатів опитування, підбиття підсумків та запропоновані шляхи щодо вирішення деяких проблем паліативної медицини Херсонщини.

Головна рушійна компонента навчання студентів у медичному коледжі - практичні заняття. Кожна клінічна дисципліна в складі своєї програми має питання, пов'язані з допомогою та доглядом за тяжкохворими. На забезпечення практичних навичок цього напрямку в коледжі створені умови наближені до реальних. Завдяки тому, що Центр практичного навчання Бериславського медичного коледжу знаходиться безпосередньо на території лікарні, студенти мають змогу постійно бути біля тяжкохворих пацієнтів, надавати необхідну допомогу в межах своєї компетентності на даний момент та долучатися до волонтерської діяльності. Практика свідчить, що робота волонтера дає можливість студентам не тільки безпосередньо застосовувати знання, але й формувати здатність до самостійного втілення сестринського процесу, працювати самостійно, реалізовувати свої здібності, сприяє їх професійній спрямованості на розвиток значущих якостей в процесі навчання і $\epsilon$ стимулом після закінчення навчального закладу зайняти достойне місце в медичній галузі.

3 метою виявлення готовності виконувати самостійно доручення, практичні маніпуляції, вести по-

\section{СПИСОК ЛІТЕРАТУРИ}

1. Стратегія розвитку паліативної допомоги в Україні на 2015-2025 роки.

2. Децик О. 3. Про необхідність удосконалення системи підготовки медичних кадрів для паліативної допомоги / О. З. Децик, Н. І. Кольцова, Ж. М. Золотарьова // Впровадження стандартів паліативної допомоги : матеріали наук.-практ. конф. ; за ред. І. П. Вакалюка, О. З. Децика. Івано-Франківськ, 2013. - С. 50-53.

3. Етичний кодекс медичної сестри України : прийнято та підписано на I з'їзді медичних сестер України в 1999 р. у Чернівцях.

4. Стан, проблеми і перспективи впровадження національної стратегії розвитку системи паліативної допомоги в Україні до 2022 року / В. М. Князевич, А. В. Царенко, І. В. Яковенко, О. П. Брацюнь // Часопис «Фітотерапія». 2013. - № 4. - C. 4-7. стійний догляд за тяжкохворими після отримання диплому на своєму робочому місці проведено анкетування - опитування серед студентів IV курсу. 89 \% опитаних із впевненістю відповіли - «Так».

Анкетування було проведено також і серед студентів І-ІІ курсів на готовність до волонтерської роботи з інкурабельними пацієнтами. До початку вивчення таких дисциплін, як «Основи медсестринства, «Догляд за хворими та медична маніпуляційна техніка», «Медична психологія та основи міжособистісного спілкування» - показник склав 54 \%. Та після проходження курсу вищевказаних дисциплін, ряду заходів із відповідної тематики - показник склав вже 82 \%.

Висновки. На виконання завдань Стратегії розвитку паліативної допомоги в Україні в коледжі й надалі планується розвиток даного питання, пам'ятаючи про те, що насамперед викладач повинен донести до студентів усвідомлення мети паліативної допомоги, яка полягає в підтримці якості життя у його фінальній стадії, максимальному полегшенні фізичних та моральних страждань пацієнта та його близьких, а також збереження людської гідності пацієнта наприкінці земного життя.

Паліативна допомога, паліативна медицина, науково-методичне забезпечення вимагає подальшого удосконалення та систематичного розвитку відповідно до умов розвитку сучасного суспільства та за умов реформування системи охорони здоров'я.

5. Резуненко Ю. К. Проблеми підготовки фахівців 3 паліативної та хоспісної медицини в вищих медичних навчальних закладах / Ю. К. Резуненко, О. М. Ковальова, Н. А. Сафаргаліна-Корнілова // Паліативна допомога в Україні: складові та шляхи розвитку : матеріали наук.-практ. конф., 18-19 вер. 2014 р., м. Харків ; за ред. В. М. Князевича, Ю. І. Губського, А. В. Царенка. - К., 2014. - 92 c.

6. Чернишенко Т. І. Підготовка медичних сестер з паліативної допомоги в Україні / Т. І. Чернишенко // Міжнародний журнал «Реабілітація та паліативна медицина». 2015. - № 2 (2). - С. 78-83.

7. Ястремська С. О. Роль медичних сестеру паліативній (хоспісній) допомозі / С. О. Ястремська, О. С. Усинська // Медсестринство. - 2011. - № 4. - С. 4-7. 